University of South Carolina

Scholar Commons

5-1999

\title{
The Religious Right in Court: the Decision Making of Christian Evangelicals in State Supreme Courts
}

\author{
Donald R. Songer \\ University of South Carolina - Columbia, dsonger@sc.edu \\ Susan J. Tabrizi \\ State University of New York at Stony Brook
}

Follow this and additional works at: https://scholarcommons.sc.edu/poli_facpub

Part of the Law Commons, Political Science Commons, and the Religion Commons

\author{
Publication Info \\ Published in Journal of Politics, Volume 61, Issue 2, 1999, pages 507-526. \\ http://www.journalofpolitics.org/ \\ (C) 1999 by Cambridge University Press for the Southern Political Science Association
}

This Article is brought to you by the Political Science, Department of at Scholar Commons. It has been accepted for inclusion in Faculty Publications by an authorized administrator of Scholar Commons. For more information, please contact digres@mailbox.sc.edu. 


\title{
RESEARCH NOTES
}

\section{The Religious Right in Court: The Decision Making of Christian Evangelicals in State Supreme Courts}

\author{
Donald R. Songer \\ University of South Carolina \\ Susan J. Tabrizi \\ State University of New York at Stony Brook
}

\begin{abstract}
Much has been written recently about the emergence of evangelicals and others often labeled the "new Religious Right" in American politics. However, little attention has been paid to whether offcials who have been socialized in the denominations characterized as being part of this Religious Right actually behave differently in office from those brought up in other religious traditions. The present study begins such an inquiry by examining differences in the voting behavior of state supreme court justices in three issue areas. Evangelical justices were found to be significantly more conservative than mainline Protestant, Catholic, and Jewish justices in death penalty, gender discrimination, and obscenity cases throughout the time period from 1970 to 1993 . These findings suggest that religious affiliation is an indicator of a source of judicial values that is independent of partisan sources of values that have been discovered in previous research.
\end{abstract}

$\mathbf{R}$ ecent trends in politics seem to signal an apparent rise in the influence of the Religious Right in American politics. While the impact of the new Religious Right in political parties, elections, legislative politics, and presidential politics has become the focus of extensive recent commentary, its significance for the courts has been largely ignored. This paper seeks to determine if membership in evangelical denominations affects the votes of state supreme court justices in cases regarding obscenity, the death penalty, and gender discrimination.

It has long been known that religion has a role in determining political attitudes and guiding political behavior (Guth and Green 1991; Hertzke and Fowler 1995; Leege and Kellstedt 1993; Rozell and Wilcox 1995; Smidt 1989; Wald 1992; Wilcox 1986, 1996). David C. Leege writes that "religious beliefs and religious groups are at the foundation of a culture" (Leege 1993). Thus, religious affiliation may provide a useful indicator of judicial values that has been ignored by previous studies examining the impact of judges' values on their decisions.

Our hypothesis is that the judiciary is no exception to the influence of religion and that religion in fact helps to shape the very decisions justices make in specific issue domains. We expect that religious affiliation is an indicator of a set of powerful socialization agents that may contribute to the development of political 
attitudes in judges and that those attitudes will in turn affect the decisions of those judges. In particular, this analysis will focus on the effect of the affiliation of judges with evangelical Protestantism upon the decision making of those state supreme court justices. ${ }^{1}$ The aforementioned involvement of evangelicals in the contemporary political debate makes this a timely and important topic in American politics.

\section{Traditional Evangelical Political Involvement}

Evangelical political involvement, although the subject of increasing attention in the 1980s and 1990s, is not solely a product of these two decades. In reality, evangelical involvement can be traced back to the Puritan roots of early American communities, alternately prominent and introverted over the decades until its featured role today.

In the nineteenth century, evangelicalism ${ }^{2}$ was the dominant religious tradition in America (Himmelstein 1990; Smidt 1989; Wald 1992; Wilcox 1988). But with the public relations defeat in the early twentieth century of the Scopes trial, in which some evangelicals waged a battle against the teaching of evolution in schools, many evangelicals retreated from the political landscape (Himmelstein 1990; Speer 1984; Wald 1992).

With the growing importance of social issues in American politics during the 1960s and 1970s, evangelical political involvement began to reemerge into the mainstream (Himmelstein 1990, Wald 1992, Wilcox 1988, 1996). The 1970s saw the election of Jimmy Carter, a born-again evangelical, to the presidency. In 1979, Reverend Jerry Falwell, with prompting and support from the political right and conservative business interests, set up the Moral Majority as an organizational body intended to serve as a mobilizing force for the growing evangelical movement.

Although the presidential campaign of Republican Pat Robertson was unsuccessful in 1988, his response in creating the Christian Coalition in 1989 and its activity in politics thereafter is testament to the staying power of the Religious Right. Recent political activity in the congressional elections of 1994 as well as the presidential bid of Pat Buchanan, a conservative Catholic, in 1996 suggest the continued and diversifying influence of religion in American politics (Deckman 1995; Green and Guth 1988; Green, Guth, and Hill 1993; Guth and Green 1991; Rozell and Wilcox 1995; Wilcox 1996). Studies indicate that evangelicals, both in the mass public and among political elites, hold conservative

\footnotetext{
${ }^{1}$ Throughout this paper the term "state supreme court" will refer to the highest appellate court in each state.

${ }^{2}$ A definition of the the term "evangelical" is a major obstacle in the literature. Although we will specify a working definition for the term in the context of our study later in the paper, in this context it refers to white Protestant denominations that believe in biblical inerrancy and salvation through Jesus Christ.
} 
issue stances and are increasingly active in terms of electoral turnout and political lobbying (Guth and Green 1991; Kellstedt, Smidt, and Kellstedt 1991; Rozell and Wilcox 1995; Tabrizi 1996; Wald 1992; Wilcox 1996).

The present study will attempt to ascertain if the influence of the Religious Right on American society can be evidenced in the American judicial system, specifically in the votes of evangelical justices sitting on state supreme courts, in the areas of obscenity, the death penalty, and gender discrimination. We hypothesize that the conservative leanings of the Religious Right will be reflected in these votes, suggesting that evangelical religious values have an impact on American politics beyond the electoral ballot box.

\section{A Conceptual Definition of Evangelicals}

A major dilemma when studying the political behavior of evangelicals comes from the ambiguousness of the term itself. Three approaches have frequently been used to identify evangelicals: doctrine, self-identification, and denominational affiliation (Wilcox, Jelen, and Leege 1993). Classifying evangelicals by religious doctrine yields a religiously heterogeneous group with regard to denominational affiliation but can be difficult to operationalize. Self-identification consists of including as evangelicals those people that identify themselves as such. The obvious problem here is that there is no required consistency as to the reasons why some identify themselves as evangelical, and thus the term becomes completely subjective.

For this study, we adopt the third approach: defining evangelicals by membership in a religious denomination. While denominational identification does not always get at the intricacies of belief that may create marked differences in people's religious and political attitudes, it has the virtue of producing a highly reliable measure.

Moreover, Kellstedt and Green (1993) state that a "denomination is a set of religious institutions that are formally linked to one another, and which share common beliefs, practices and commitments" (54). They suggest that the roles religious organizations play in creating similar views among their members and, even more basically, the influences they have in early socialization result in denominational preference being a reflection of a "personal attachment to a particular version of such a tradition" (54).

Thus, we expect that denominational affiliation will be a valid indicator of political beliefs. Admittedly we are unable to explore concepts such as religious salience and participation that have been shown to be factors in the impact religion has on politics. However, these aspects of religious beliefs occur within the context of a particular denomination, indicating that they are shaped by that initial environment (Kellstedt and Green 1993).

The argument is that just as party identification reflects certain beliefs of members independent of ideological intensity and activity, denominational 
preference "may encapsulate differences in belief practice and commitment, even for individuals with nominal religiosity" (55). Because denominational affiliation cuts across the lines of party identification, we hypothesize that religion reflects a source of attitudes that is, at least in part, independent from the partisan sources of attitudes that have been more thoroughly examined in studies of judicial behavior.

We will be adopting Kellstedt and Green's classification of religious denomination for application in this study. The authors have constructed this scheme using a classification system based on distinctions between denominational families and religious movements, ultimately grouping denominations according to "comparable beliefs and ethos" (58). ${ }^{3}$

Kellstedt and Green (1993) recognize that these categories are often hard to measure and thus defining denominations based on them is imprecise. They attempt to overcome these difficulties by using the family and movement categories together to define religious traditions. Mainline Protestants include ritualistic families influenced by church movements: Anglican-Episcopal; Congregational-United Church of Christ; Lutheran-Evangelical Lutheran Church in America; Methodist-United Methodist Church; Nondenominational Mainline; Presbyterian-Presbyterian Church (USA); Reformed-Reformed Church in America; Restorationist-Christian Church (Disciples of Christ). Evangelical Protestants include pietist families and sect movements: BaptistSouthern Baptist Convention, American Baptist Churches USA, Baptist General Conference; Holiness - Christian and Missionary Alliance, Church of the Nazarene, Free Methodist Church, Salvation Army, Wesleyan Church; LutheranMissouri Synod, Wisconsin Synod; Nondenominational Evangelical; Pentecostal-Assemblies of God, Church of God (Tennessee); PresbyterianPresbyterian Church in America, Orthodox Presbyterian Church; ReformedChristian Reformed Church; Restorationist-Churches of Christ; OthersSeventh-Day Adventists, Mennonite Church, Evangelical Free Church, Evangelical Covenant Church, Plymouth Brethren (Kellstedt and Green 1993).

\footnotetext{
${ }^{3}$ Kellstedt and Green (1993) divide denominational families (groups of individual denominations sharing historical, theological and ethnic/racial characteristics) into two categories-ritualistic and pietist (Swierenga 1990, 151-52; cf. Sommerfield 1968) - with regard to levels of institution and centralization within the denominational family. Ritualistic families stress "centralized religious authority, formalized rituals, and official creeds" (57). Denominations are pluralistic within the family. "Pietist families place greater emphasis on the unmediated contact between believers and God and are thus characterized by decentralized religious authority, informal worship, individual religious experience, and emphasis on righteous behavior" (57). These denominations are particularistic within the denominational family.

Religious movements (attempts at change within denominations) are classified as church or sect movements (Stark and Bainbridge 1985). Church movements seek accommodation and the reduction of differences with a broad culture. They tend to produce liberal denominations with an emphasis on acceptance. Sect movements seek "separation from the broader culture," producing conservative denominations with a conversionist ethos (Kellstedt and Green 1993, 57-58).
} 


\section{Research Design}

The data for the analyses below consist of the universe of the obscenity and gender discrimination policy decisions with published opinions and a random sample of 30 death penalty decisions per year for the years 1970 through $1993 .{ }^{4}$ Westlaw searches were designed to identify all the published cases in each issue area. Decisions that decided purely factual disputes (e.g., whether the defendant was actually the owner of the obscene materials found in the search of her house) without interpreting the meaning of any precedent or addressing any policy question were excluded from analysis. After cases with missing data were excluded, the number of judges' votes suitable for analysis was 3,909 from death penalty cases, 437 votes from gender discrimination cases, and 2,023 from obscenity cases. Data on the background characteristics of the judges whose votes are analyzed were obtained from standard biographic sources including The American Bench and Who's Who in American Law.

The unit of analysis for the models described below is the vote of each judge on each case. For each issue area, an integrated model was created to assess the effects of judicial attitudes, changing policy from the United States Supreme Court, contextual political influence, and case facts specific to the particular issue area.

A dilemma facing those seeking to increase our understanding of appellate court decision making is that integrated models will be incompletely specified unless they include the particular case facts that are most relevant for the type of cases examined. These case facts differ among different types of issues. Consequently, it is impossible to develop comparable models for different case types unless the models are underspecified. Given this dilemma, the present study creates separate models for each of the three issue areas examined, with a core of common variables plus the addition of separate case facts for each issue area. ${ }^{5}$ Common measures of judicial attitudes, Supreme Court change, and contextual influence were coded for all cases in each of the three issue areas. In addition, since the main theoretical interest of the present analysis is the effect of the religious affiliations of judges, the same measures of judge religion were used for the three issue areas.

Case facts used in each model were derived from previously successful integrated models of appellate decision making in each issue area. More specifically, the case facts used in the model of death penalty decisions combined facts previously discovered to be significantly related to state death penalty decisions

\footnotetext{
${ }^{4}$ Since there were more than 10 times as many death penalty decisions than gender discrimination decisions in most years, it was not feasible to code all the death penalty decisions.

${ }^{5}$ However, the addition of case facts does not appear to substantively affect conclusions about the effect of religion on judicial votes. When a model containing only the common core variables (without case facts) was run, the direction and level of significance was the same in all three issue areas as in the more fully specified models presented below.
} 
(Brace and Hall 1995) and United States Supreme Court death penalty decisions (George and Epstein 1992) in partially overlapping time periods. The case facts used in the model of gender discrimination cases were drawn from those used by Wolpert (1991) in her analysis of Supreme Court decision making and by CrewsMeyer and Anderson (1994) in their analysis of decisions in the U.S. Courts of Appeals and state supreme courts. The case facts used in the model of obscenity decision making were derived from the analysis of obscenity decisions in the U.S. Courts of Appeals (Songer and Haire 1992).

Because least squares regression is inappropriate when the dependent variable is dichotomous, as in the present analysis (Aldrich and Nelson 1984), the parameters of the models were estimated by logit, a maximum likelihood estimation technique. This method produces estimates for the parameters of a model's independent variables in terms of the contribution each makes to the probability that the dependent variable falls into one of the designated categories (e.g., a liberal or conservative vote). For each independent variable, a maximum likelihood estimate (MLE) is calculated along with its standard error (SE). The MLEs represent the change in the logistic function that results from a one-unit change in the independent variable.

\section{Specifying the Components of an Integrated Model}

A consensus appears to be growing that for most courts in the United States (except possibly the United States Supreme Court), judicial decisions are the result of a myriad of forces that limit and shape (but do not eliminate) the expression of judicial preferences (e.g., Brace and Hall 1995a; George and Epstein 1992; Hall and Brace 1992, 1994; Emmert 1992; Songer and Haire 1992). All share the view that judicial decisions are the product of a complex set of relationships among interacting variables.

Drawing on the groundbreaking work of Richardson and Vines (1970), virtually all of the new wave of integrated models of appellate court decision making include, in some fashion, the notion that judges respond to pressures from both the legal and the democratic subcultures. Integrated models of judicial decision making also typically include one or more indicators of judicial values and contextual or environmental pressures that may impinge on judicial decision making.

The dependent variable for each of the models is the direction of each judge's vote. A liberal vote was coded 1 and a conservative vote was coded 0 . A liberal vote was defined as one striking down the death penalty or overturning a sentence of death in a death penalty case; or that narrows the gender gap in a gender discrimination case; or that supports greater protection for asserted First Amendment claims, or is less restrictive of material that is alleged to be obscene in obscenity cases. 


\section{Independent Variables Common to Models in All Three Issue Areas}

The focus of the analysis below was the effect of judges' religion on their votes. Three dummy variables were created as indicators of judge religion. The variable Catholic was coded 1 if the judge was a Roman Catholic, 0 otherwise. Similarly, the variable "Jewish" was coded 1 if the judge was Jewish and 0 otherwise. Finally, the variable "Evangelical" was coded 1 if the judge was a white/Caucasian, evangelical Protestant and was coded 0 for all other judges. Evangelicals were defined as all those who claimed to be affiliated with the Southern Baptists, American Baptist, or the Baptist General Conference; any of the Holiness churches including the Christian and Missionary Alliance, Church of the Nazarene, Free Methodist Church, Wesleyan Church; the Missouri Synod or Wisconsin Synod Lutherans; Orthodox Presbyterians or the Presbyterian Church in America; Pentacostals like the Assemblies of God, Church of God, or the Christian Reformed Church; or the Churches of Christ, Seventh-Day Adventists, or the Evangelical Free Church. ${ }^{6}$ The excluded category that serves as the reference group for these three dummy variables is the group of mainline Protestants, including members of the Episcopal Church, the United Church of Christ, the Evangelical Lutheran Church in America, the United Methodist Church, and the Presbyterian Church USA. ${ }^{7}$

Building on previous integrated models of judicial decision making, the models below also contain common indicators of judicial attitudes, changing Supreme Court policy, and a measure of the context of judicial decision making. In addition, each model contains a series of variables to capture the effects of the case facts hypothesized to be most relevant for each given policy area. A summary list of all the variables used in the models is provided in table 1.

Unfortunately, direct, independent measures of the ideology of the hundreds of judges who have served on the 52 state supreme courts since 1970 do not exist; nor is it feasible to obtain them. Therefore, the best that can be done is to select an indicator that will serve as an inferential measure of judicial ideology. The best indicator that is readily available for most state supreme court judges is political party affiliation. A wide variety of studies suggests that party identification provides a rough indicator of the ideology of appellate court judges and that Democratic judges (coded 1) are generally more liberal than Republican judges (coded 0) in most issue areas of civil liberties and economic regulation (Goldman 1975; Hall and Brace 1992; Songer and Haire 1992; Tate 1981).

\footnotetext{
${ }^{6}$ This classification is taken from Kellstedt and Green 1993.

${ }^{7}$ Judges whose religion could not be ascertained or whose religious affiliation did not fit one of these four categories (e.g., Russian Orthodox) were excluded from analysis. The total number of cases excluded from analysis because of missing data (primarily missing data on the religion or political party of the judge) was 1,518 votes for death penalty cases, 961 for obscenity cases, and 313 for gender discrimination cases.
} 
TABLE 1

\section{Summary of Variable Descriptions}

\begin{tabular}{|c|c|}
\hline \multicolumn{2}{|r|}{ Variables Common to All Models } \\
\hline Party identification & $1=$ Democrat, $0=$ Republican \\
\hline Prosecutor & $1=$ former prosecutor; $0=$ no prosecutorial experience \\
\hline Supreme Court policy & $\begin{array}{l}0=\text { Warren Court, adding } 1 \text { for each replacement of a Warren Court } \\
\text { justice with a Republican appointee; maximum }=7\end{array}$ \\
\hline State citizen ideology & $\begin{array}{l}100=\text { most liberal mass political ideology } \\
0=\text { most conservative mass ideology }\end{array}$ \\
\hline Elected judge & $\begin{array}{l}1=\text { judge from state with either partisan or nonpartisan election of } \\
\text { judges; } \\
0=\text { merit, appointment, or legislative selection of judges }\end{array}$ \\
\hline Party competition & $1=$ complete competition, $0=$ no competition \\
\hline $\begin{array}{l}\text { Evangelical } \\
\text { Catholic } \\
\text { Jewish }\end{array}$ & $\begin{array}{l}1=\text { judge is white/Caucasian evangelical Protestant, } 0=\text { other } \\
1=\text { judge is Roman Catholic, } 0=\text { other } \\
1=\text { judge is Jewish, } 0=\text { other }\end{array}$ \\
\hline \multicolumn{2}{|c|}{ Case Facts: Death Penalty } \\
\hline $\begin{array}{l}\text { Female victim } \\
\text { Police officer victim } \\
\text { Multiple murders? } \\
\text { Rape } \\
\text { Robbery } \\
\text { Death-qualified jury? } \\
\text { Crime }\end{array}$ & $\begin{array}{l}1=\text { yes, } 0=\text { no } \\
1=\text { yes, } 0=\text { no } \\
1=\text { yes, } 0=\text { no } \\
1=\text { defendant accused of murder }+ \text { rape, } 0=\text { no rape charge } \\
1=\text { defendant accused of murder }+ \text { robbery, } 0=\text { no robbery charge } \\
0=\text { defendant say yes, } 1=\text { no claim } \\
0=\text { intentional murder, } 1=\text { lesser charge }\end{array}$ \\
\hline \multicolumn{2}{|c|}{ Case Facts: Gender Discrimination } \\
\hline $\begin{array}{l}\text { Facial } \\
\text { Policy type } \\
\text { Benign }\end{array}$ & $\begin{array}{l}1=\text { facial discrimination, } 0=\text { no } \\
1=\text { civil, } 0=\text { criminal } \\
1=\text { discrimination defended as benign } \\
0=\text { no such defense }\end{array}$ \\
\hline Real differences & $\begin{array}{l}1=\text { discrimination defended as response to real differences between } \\
\text { genders, } 0=\text { no such defense }\end{array}$ \\
\hline Scrutiny & $\begin{array}{l}2=\text { strict scrutiny } \\
1=\text { intermediate scrutiny } \\
0=\text { rational basis test }\end{array}$ \\
\hline \multicolumn{2}{|l|}{ Case Facts: Obscenity } \\
\hline Film & $1=$ alleged obscene material was a film or video, $0=$ other \\
\hline Text & $1=$ alleged obscene material was primarily textual material, $0=$ other \\
\hline Pictoral & $\begin{array}{l}1=\text { alleged obscene material was a magazine that was primarily } \\
\text { pictures rather than text, } 0=\text { other }\end{array}$ \\
\hline Adults & $1=$ alleged obscene material was not restricted to adult use, $0=$ other \\
\hline First Amendment & $\begin{array}{l}1=\text { defendant attacked restriction on First Amendment grounds, } \\
0=\text { other }\end{array}$ \\
\hline Scienter & $\begin{array}{l}1=\text { defendant's primary defense was that prosecution had not proved } \\
\text { scienter; } 0=\text { other }\end{array}$ \\
\hline
\end{tabular}


Prior career experiences may also contribute significantly to the socialization of judges. In particular, previous scholarship suggests that judges with prior experience as a prosecutor will be more conservative in civil liberties cases than judges without such experience (Tate 1981). Thus, as a second measure of judicial attitudes, we coded whether a judge had served as a prosecutor (coded 1) or not (coded 0 ) prior to becoming a justice.

Although several dramatic examples of noncompliance by lower courts have been documented, the available evidence suggests that the normal pattern is the acceptance by lower courts of clear precedent established by the Supreme Court (Baum 1978; Songer and Sheehan 1990). Moreover, a number of studies suggest that across a broad spectrum of issue areas, lower courts are responsive to changing Supreme Court policy (Baum 1980; Johnson and Canon 1984; Songer 1987; Songer and Haire 1992; Songer, Segal, and Cameron 1994). In each of the three issue areas analyzed below, the legal model suggests that state supreme courts will be responsive to the changing constitutional interpretations by the Supreme Court. Unfortunately, no easily quantifiable measure of changing Supreme Court policy that would apply to all three areas is available. Since it is well established that changing Supreme Court policy is closely related to the changing ideological composition of the Court, the analysis below uses, as a surrogate for such a direct measure of changing policy, a measure of the changing ideological composition of the Court. Specifically, we adapted the measure used by Segal (1984) that takes the value of zero during the Warren Court and increases by one each time a Warren Court member was replaced by an appointee of Nixon, Reagan, or Bush. It is expected that state supreme courts will respond directly to changing Supreme Court policy. ${ }^{8}$

Strong relationships between the votes of state court judges and the values that are dominant in the political environment of the state are expected even though previous studies have not clearly established the precise mechanisms that link environmental values to judicial votes. This relationship between the environment and judges' votes may be mediated through a selection system in which local elites work to insure the selection of judges who share the dominant state values. Alternatively, even in the absence of any direct attempt to select judges who mirror the dominant political values, judges may experience the same socialization experiences that produced a given set of values in other state residents and adopt similar values as a result. Finally, even when judges do not share local values, they may respond to those values in order to maintain the legitimacy of their court, to assure their own reelection or reappointment, or to avoid informal social sanctions. Since none of these possible links are mutually exclusive, it is possible that any observed links between judicial voting and the dominant state political values result in part from all three mechanisms.

\footnotetext{
${ }^{8}$ Since liberal values of the dependent variable are coded 1 while higher values of the change variable indicate a more conservative Supreme Court, it is expected that the sign of the relationship between these two variables will be negative.
} 
An extensive literature has documented an association between the dominant values of the home state or region of elites and the political positions they take. Most of the studies of such linkages have used region as a surrogate for common political culture or values. Although the utility of region has been demonstrated in many analyses of both courts and legislatures, the variable provides at best only a rough indicator of local opinions and values. In addition, region as a variable is not able to capture change over time in local opinions or moods. Recently, however, a new measure has been developed that overcomes these shortcomings of region as a measure of the influence of state culture and values. Berry et al. (1998) have created a measure of citizen ideology for each state for each year from 1960 through 1993. The score is derived from an analysis of the voting behavior of the members of Congress from each state in combination with an analysis of the partisan composition of state and national officeholders from the state. Analyses reported by Berry et al. provide convincing evidence that this measure is both valid and highly reliable. We adopt this measure, called Citizen Ideology, as a control for the dominant values of each state. The variable theoretically runs from 0 (most conservative) to 100 (most liberal). ${ }^{9}$

Recent analyses by Hall and Brace (1989, 1992, 1994a) suggest that the institutional characteristics of state courts may affect the extent to which the values of judges are reflected in their decisions. To control for such effects, we added measures of two institutional features that appear to have the most direct impact on judicial voting: the method of judicial selection in the state and the extent of party competition in the state political system. As our control for method of selection, we employed a simple dichotomy between states that directly elect their judges (either through partisan or nonpartisan elections), coded 1, and all other states, coded 0 . For our measure of state party competition, we employed one of the most widely used indicators, the folded Ranney Index. This composite measure, based on the percentage of seats won by each party in state house and senate elections, the percentage of gubernatorial victories by each party, and the proportion of the Democratic vote in gubernatorial elections, ranges from a value of 0.50 for no competition to 1.0 for perfect party competition. For the years in our analysis before 1978, the index constructed for the years 1962-73 is used (Ranney 1976). For the remaining years in our analysis, the index derived from 1981-88 data (Bibby et al. 1990) is used.

\section{Case Facts Used as Controls for Each Model}

Most integrated models of judicial decision making have derived the case facts included in their analyses from among the readily identifiable facts that ju-

\footnotetext{
${ }^{9}$ While we believe that the measure of citizen ideology is superior to all commonly used measures of region, we reran the models below twice, once using a simple North-South regional dichotomy and once with a four-way classification of region. Use of these measures of region in place of citizen ideology did not substantially reduce the effects of religion reported below.
} 
dicial doctrine has identified as relevant to the resolution of the conflict before the court. Both the advocates of the importance of the legal model for judicial decision making and those who maintain the primacy of judicial attitudes are in agreement that a properly specified model of judicial decision making must identify the set of case facts that are most relevant to judicial decisions in a given case category. The case facts employed in each model below are primarily viewed as control variables to insure that any associations discovered between religion and judicial decisions are not an artifact of some correlation between particular types of cases and the concentration of particular religions in regions giving rise to those types of cases.

The model of death penalty decisions includes three victim characteristics that Hall and Brace (1994a, 1994b) found to be associated with support for the death penalty. Thus, it is expected that conservative votes will be more likely if the victim was female, elderly, or a police officer. In addition, the model below tests their expectations that conservative decisions are more likely if the murder occurred in conjunction with a rape or a robbery or if multiple murders were committed. George and Epstein's (1992) analysis of death penalty decisions by the U.S. Supreme Court suggests that liberal decisions are more likely if the defendant was charged with some crime other than intentional murder or if the defendant argued that the death penalty should be overturned because the jury was death qualified. ${ }^{10}$

The model of gender discrimination decisions includes several variables derived from Supreme Court precedent. First, liberal decisions are expected to be more likely when the challenged statute discriminates on its face or the law is a civil rather than a criminal regulation. Second, equal protection doctrine recognizes that if males and females are not similarly situated in regard to the activity at issue, then different treatment does not violate equal protection. Therefore, a statute defended on the grounds that there are "real differences" between the sexes should have a better chance of being upheld than one not based on such substantial differences. Similarly, the claim that the differential treatment is "benign" may also increase the chances that the challenged action will be upheld. Therefore, the presence of either of these two defenses should decrease the chance of a liberal vote. In addition, equal protection claims often turn on the level of scrutiny employed by the courts. Therefore, the higher the level of scrutiny that the government concedes should be employed, the more likely a liberal vote. $^{11}$

The model of obscenity decisions includes three indicators of the type of material alleged to be obscene: whether the material was primarily written text, a film, or from a magazine. Dummy variables were created for each of these types

\footnotetext{
${ }^{10}$ For further details on the details of the coding of these variables, see Hall and Brace 1994a and George and Epstein 1992.

${ }^{11}$ For further elaboration on the conceptualization of these variables and the details of their coding, see Crews-Meyer and Anderson 1994.
} 
of material, taking the value 1 if the material alleged to be obscene was of that type and coded 0 otherwise. The excluded category was live entertainment that was alleged to be obscene. In addition, courts were expected to grant governments more power to regulate material intended for children. Finally, courts were expected to be more likely to make a liberal decision when the defendants claimed a First Amendment violation and less likely to make a liberal decision when the defendant's primary claim was that scienter was not established. Each of these variables was coded 1 if present and 0 if not present.

\section{Religion and Judges' Votes}

The three models of Supreme Court decision making presented below allow the investigation of the effect of judges' religious affiliation on their voting behavior under controls for judicial preferences, changing Supreme Court policy, contextual and institutional variation, and case facts appropriate for each issue area. The findings are presented in tables $2-4$. To test each of the directional hypotheses described above, one-tailed tests of statistical significance are reported.

The results for death penalty cases are presented in Table 2. Judicial preferences appear to be strongly related to the voting choices of the judges. Party

TABLE 2

Logit Analysis of the Impact of Judges' Religion on the Likelihood of a Liberal Vote in State Supreme Courts in Death Penalty, Obscenity, and Gender Discrimination Cases, 1970-1993

\begin{tabular}{lccc}
\hline & Death & & Gender \\
Independent & Penalty & Obscenity & Discrimination \\
Variables & MLE & MLE & MLE \\
& $(\mathrm{SE})$ & $(\mathrm{SE})$ & $(\mathrm{SE})$ \\
\hline Party identification & $0.355^{* * *}$ & $0.348^{* *}$ & -0.416 \\
& $(.102)$ & $(.119)$ & $.312)$ \\
Prosecutor & $-0.139^{*}$ & 0.152 & 0.016 \\
& $(.071)$ & $(.096)$ & $(.009)$ \\
Supreme Court policy & $-0.441^{* * *}$ & $-0.147^{* *}$ & 0.234 \\
& $(.030)$ & $(0.50)$ & $(.141)$ \\
State Citizen ideology & $0.033^{* * *}$ & $0.032^{* * *}$ & $0.066^{* * *}$ \\
& $(.003)$ & $(.003)$ & $(.012)$ \\
Elected judge & 0.131 & -0.092 & 0.323 \\
& $(.077)$ & $(.100)$ & $(.302)$ \\
Party competition & $-0.014^{* * *}$ & $-0.009^{*}$ & $-0.058^{* * *}$ \\
& $(.003)$ & $(.004)$ & $(.014)$ \\
Evangelical & $-.324^{* * *}$ & $-0.446^{*}$ & $-0.689^{*}$ \\
& $(.094)$ & $(.197)$ & $(.352)$ \\
Catholic & $-0.212^{*}$ & $-0.369^{* *}$ & 0.098 \\
& $(.119)$ & $(.137)$ & $(.304)$ \\
Jewish & 0.256 & -0.101 & 0.430 \\
& $(.179)$ & $(.279)$ & $(.606)$
\end{tabular}




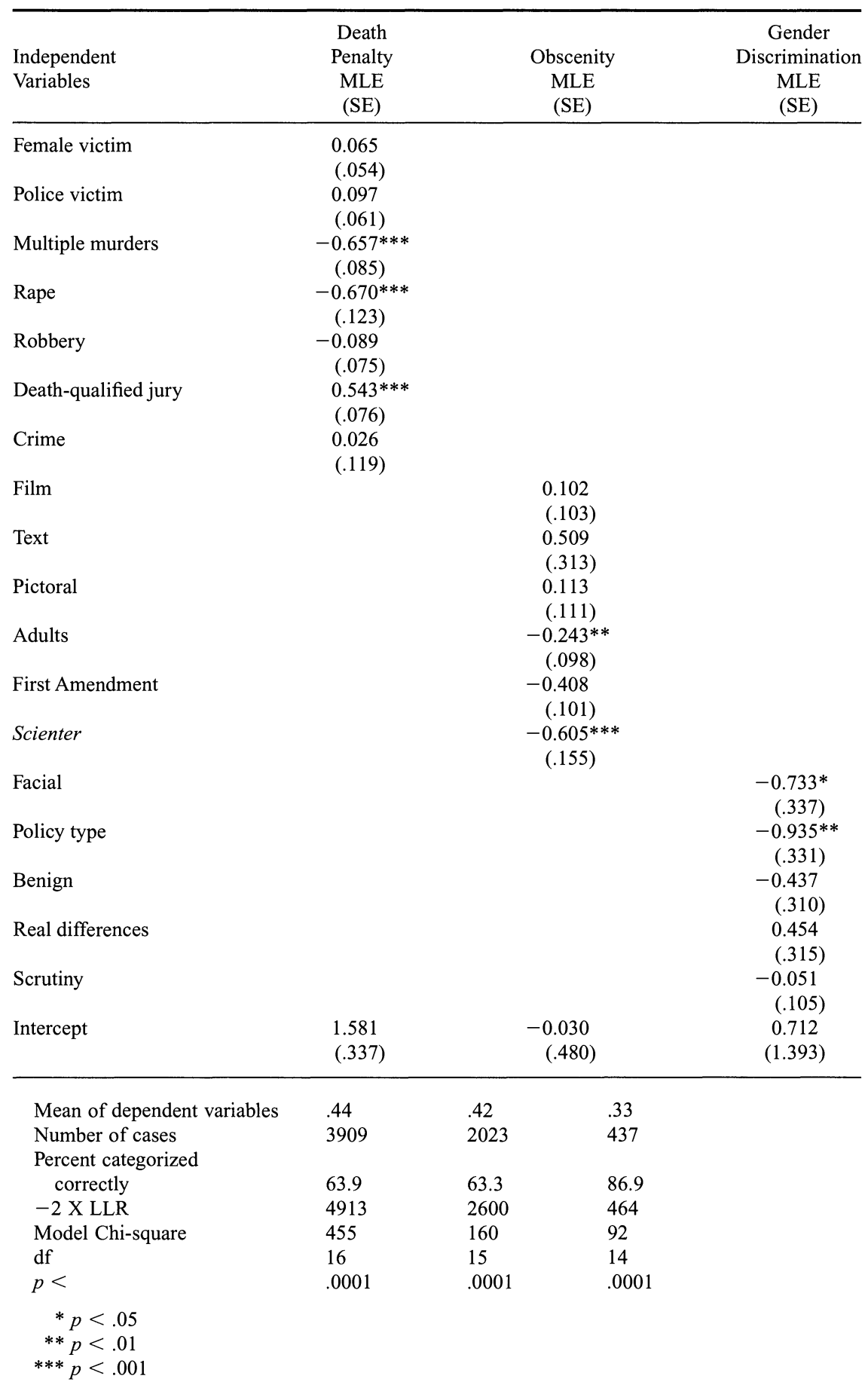


identification is arguably only a very rough indicator of differences in the political values of judges. Nevertheless, the coefficient for this variable is robust and statistically significant. That is, in death penalty cases, Democratic judges are substantially more likely than their Republican colleagues to cast liberal votes under controls for variations in changing precedent and contextual pressures. In contrast, the association between prosecutorial experience and judicial votes is negative, indicating that former prosecutors are significantly more likely than other judges to vote to uphold the death penalty. These findings strongly reinforce the conclusions of other studies that have found that the political values of appellate court judges are important influences on judicial decisions.

Influences from the legal subculture also appear to have important effects on judicial votes. The decisions of state court judges become significantly more conservative as the Supreme Court shifted steadily to the right during the Burger and Rehnquist Courts. While the control variable used to capture changing Supreme Court policy provides only a rough indicator of changing precedent, the results are consistent with the expectation that judges are responsive to some influences from the legal subculture. Together with the findings on the influence of the political preferences of judges, these results provide strong confirmation for the assertion of Richardson and Vines (1970) and others that judicial votes can best be understood as a resultant of the sometimes conflicting pressures from the legal and democratic subcultures.

While it is increasingly common for studies of appellate court decision making to examine the effects of both judicial attitudes and legal influences, contextual effects have been less frequently examined. The analysis presented in table 2 suggests that these oversights may be unfortunate. The association between the citizen ideology of each state and the pattern of judicial decisions is strong and statistically significant. Judges from conservative states were substantially more likely to cast conservative votes than their brethren immersed in more liberal cultures.

Overall, the results of the analysis in Table 2 demonstrate the utility of integrated models of judicial decision making. The results for obscenity and gender discrimination cases reported in Table 2 are similar. They suggest that no singlefactor explanations of judicial behavior (e.g., mechanical jurisprudence or the Attitudinal Model) are satisfactory accounts of voting on state supreme courts. Instead, judicial decisions appear to be the result of the interactions among a complex set of forces including judicial values, legal forces, and contextual pressures. As predicted from earlier studies, Democratic judges are substantially more liberal than their Republican colleagues, and former prosecutors are more conservative. But judicial attitudes are not the whole story; the decisional trends of state court judges were also highly responsive to the changing trends on the Supreme Court.

Turning to the main focus of this analysis, the effect of judges' religious affiliations is also evident in the model of death penalty decisions. As can be seen 
from table 2, evangelical judges were significantly more likely to vote to uphold the death penalty than were either mainline Protestants or Jewish judges, and they were marginally more supportive of the death penalty than were Catholics. These findings are analogous to the findings from studies of the mass public that have found that evangelicals tend to support a strong "law and order" orientation.

Within the context of this integrated model of judicial decision making, the religious affiliation of the judges appears to exert a substantial influence. As hypothesized, evangelical judges were substantially more likely to cast conservative votes than their mainline Protestant brethren even after the effects of party, prosecutorial experience, state citizen ideology, and changing Supreme Court policy were accounted for. Catholic judges were also more likely than mainline Protestants to support conservative outcomes, but they were less conservative than the Protestant evangelicals. Jewish judges had voting patterns that were similar to those of mainline Protestants.

The effects of religion in the obscenity decisions of the courts were similar to those discovered in death penalty cases. Obscenity cases often involve choices that most directly involve moral judgments that impinge on religous beliefs. Evangelicals in a wide variety of settings tend to support traditional values that are hostile to toleration of even soft-core pornography. Therefore, the results in Table 2 are consistent with expectations derived from the general social and moral orientations of different religious groups. Evangelical judges were significantly more likely to vote to support conservative outcomes in obscenity cases than their mainline Protestant brethren. In obscenity as in the death penalty cases, Catholic judges also were significantly more conservative than mainline Protestants and in fact appear to be almost as conservative as the evangelical judges.

The effects of religion are most clearly defined in gender discrimination cases. Catholic judges and Jewish judges appear to be slightly more liberal than mainline Protestant judges, but the differences fall short of the .05 level of statistical significance. On the other hand, evangelical judges stand out as substantially more likely to support conservative decisions than judges of any of the other three religious groups. These results are consistent with studies of mass political behavior that have found adherents of the new Religious Right to oppose abortion and the ERA and to favor the maintenance of traditional gender distinctions. The coefficients presented in Table 2 indicate that these differences are statistically significant in spite of the relatively small sample size for gender discrimination cases. The data in Table 2 also indicate that the difference in the probability of liberal votes being cast by evangelicals compared to judges of other religions is greater than the difference between Democrats and Republicans.

In all three issue areas, the coefficients for a number of the case facts included in the models appear to suggest that the state courts are responsive to Supreme Court precedent. For example, precedent creates a strong presumption that sale of sexually explicit materials to minors is more subject to government regulation 
TABLE 3

\section{Estimated Probabilities of a Liberal Vote for Different Combinations of Religion and Political Party}

\begin{tabular}{llccc}
\hline & \multicolumn{4}{c}{ Issue Area } \\
\cline { 2 - 5 } Party & Religion & Death Penalty & Obscenity & Gender Discrimination \\
\hline Democrat & Evangelical & .407 & .363 & .195 \\
Democrat & Mainline Protestant & .487 & .472 & .324 \\
Republican & Evangelical & .326 & .282 & .202 \\
Republican & Mainline Protestant & .399 & .379 & .335 \\
\hline
\end{tabular}

than sale of similar material to adults. Thus, if courts are responsive to precedent, prosecutions for sales to minors should carry a higher probability of being upheld than sales to adults (i.e., conservative decisions will be more likely when the sales are to minors). The strong negative coefficient for the variable that captured whether the action targeted children or adults is consistent with this predicted effect of precedent. More importantly, the addition of controls for the most relevant case facts in each of the three issue areas examined have virtually no effect on the strength of the relationship between judges' religious affiliation and their tendency to support the liberal position. Even under controls for these case facts, evangelical judges in all three issue areas tended to support the conservative position to a significantly greater extent than their mainline Protestant and Jewish brethren (and in gender discrimination cases they were also substantially more likely than Catholic judges to support the conservative position).

While the MLE coefficients in Table 2 can be used to indicate the directionality and (along with the standard error) statistical significance of the effect of each independent variable, the magnitude of the coefficient is not readily interpretable. Therefore, we present in Table 3 an illustration of the difference that judges' religion can make in the probability of a liberal vote for judges of each party in each of the three issue areas. The estimated probabilities derived from the MLE coefficients in Table 2 assume that the values of all variables except those for party and religion are set at their mean values. The data show that when political party is controlled, the effect of changing from a mainline Protestant to an evangelical judge decreases the probability of a liberal vote from 8 to 13 percentage points, depending on the issue area. While the magnitude of this impact is moderate, it should be noted that it is essentially the same as the effect of changing the party of the judge while holding the religion constant.

\section{Conclusions}

Our analysis of the decisions of state supreme court justices who are evangelicals provides evidence to support the claim that judges' religion has an influence 
on those votes in the areas of gender discrimination, obscenity, and the death penalty. The relationship discovered between the religion and votes of state supreme court judges is most likely a reflection of the connection between judges' religious affiliation and their attitudes. ${ }^{12}$ This is a significant finding in that we see that including religion in the group of characteristics commonly used by judicial scholars to explain judicial votes uncovers effects that have been previously missed. Controlling for party identification, prosecutor status, Supreme Court policy, citizen ideology and institutional characteristics of the state, and the relevant case facts does not negate the impact of religion. Religious denomination has an independent and notable effect on judicial decision making even when these control variables have notable effects of their own. This suggests that religious affiliation represents a set of influences on the development of the values of judges that are separate from the partisan sources that have been frequently studied.

One implication of these findings is that future studies employing the Attitudinal Model of judicial decision making should not place exclusive reliance on judges' political party as the sole surrogate for their values. Instead, a combination of political party and religious affiliation may provide a better indicator of the values of state court judges.

The effect of religion on the votes of evangelical justices is detectable despite the relatively rough indicator of denominational affiliation that we employ. Other studies delve even deeper into the relationships between issues such as religious salience (Guth and Green 1991), doctrinal beliefs (Kellstedt and Smidt 1993), church involvement and attendance (Wald, Kellstedt, and Leege 1993) and political involvement of evangelicals. The indications are that these variables do have effects on evangelical politics, and future research in the area of judicial decision making with regard to religion should attempt to address them.

As a result of these limitations, the present analysis probably underestimates the effects of religion on judges' votes in these cases. The fact that they are, nevertheless, evident in our analysis suggests that the influence religion has on politics in the electorate is present to some degree in the realm of political elites and judicial decision making.

\section{Manuscript submitted 1 May 1997}

Final manuscript received 26 May 1998

\footnotetext{
${ }^{12}$ The conclusion that attitudes provide the link between religious affiliation and judges' votes is supported by the finding that when only nonunanimous decisions of the courts are examined, the relationship is substantially stronger. Specifically, for nonunanimous decisions, the coefficient for evangelicals in death penalty cases is -.700 (compared to -.324 in all death decisions), and in obscenity cases it is -.848 (compared to -.446 in all obscenity decisions). Only in gender discrimination cases is it lower $(-.553$ compared to -.689$)$. Since it is widely believed that nonunanimous cases tend to be the kind of cases in which judges are freer to vote their ideological preferences, the strong findings in these cases reinforce the attitudinal interpretation of the effects of religious affiliation.
} 


\section{References}

Aldrich, John H., and Forrest Nelson. 1984. Linear Probability, Logit and Probit Models. Beverly Hills: Sage.

Baum, Lawrence. 1978. "Lower Court Response to Supreme Court Decisions: Reconsidering a Negative Picture." Justice System Journal 3 (summer): 208-19.

$\rightarrow$ Baum, Lawrence. 1980. "Response of Federal District Judges to Court of Appeals Policies: An Exploration." Western Political Quarterly 33(2): 217-24.

$\rightarrow$ Berry, William D., Evan J. Ringquist, Richard C. Fording, and Russell L. Hanson. 1998. "Measuring Citizen and Government Ideology in the American States, 1960-1993." American Journal of Political Science 42 (January): 337-48.

Bibby, John, Cornelius Cotter, James Gibson, and Robert Huckshorn. 1990. "Parties in State Politics." In Politics in the American States, ed. Virginia Gray, Herbert Jacob, and Robert Albritton. 5th ed. Glenview, IL: Scott Foresman.

$\rightarrow$ Brace, Paul, and Melinda Gann Hall. 1990. "Neo-Institutionalism and Dissent in State Supreme Courts." Journal of Politics 52(1): 54-70.

$\rightarrow$ Brace, Paul, and Melinda Gann Hall. 1995a. "Studying Courts Comparatively: The View from the American States." Political Research Quarterly 48(1): 5-29.

Carp, Robert A., and C. K. Rowland. 1983. Policymaking and Politics in the Federal District Courts. Knoxville: University of Tennessee Press.

Crews-Meyer, Kelley A., and Jenny R. Anderson. 1994. "A Cross-Court Model of Judicial Decision Making: Gender Discrimination Cases in State Supreme Courts and the United States Courts of Appeals." Presented at the annual meeting of the Midwest Political Science Association, Chicago.

Deckman, Melissa. 1995. "The 1994 Congressional Elections and the Role of the Christian Right." Presented at the annual meeting of the Southern Political Science Association, Tampa, FL.

$\rightarrow$ Emmert, Craig F. 1992. "An Integrated Case-Related Model of Judicial Decision Making: Explaining Supreme Court Decisions in Judicial Review Cases." Journal of Politics 54(2): 543-52.

$\rightarrow$ George, Tracy E., and Lee Epstein. 1992. "On the Nature of Supreme Court Decision Making." American Political Science Review 86 (June): 323-37.

$\rightarrow$ Goldman, Sheldon. 1975. "Voting Behavior on the United States Courts of Appeals, Revisited." American Political Science Review 69 (June): 491-506.

$\rightarrow$ Green, John C., and James L. Guth. 1988. "The Christian Right in the Republican Party: The Case of Pat Robertson's Supporters." Journal of Politics 50(1): 150-65.

$\rightarrow$ Green, James C., James L. Guth, and Kevin Hill. 1993. "Faith and Election: The Christian Right in Congressional Campaigns 1978-1988." Journal of Politics 55(1): 80-91.

Guth, James L., and John C. Green, eds. 1991. The Bible and the Ballot Box: Religion and Politics in the 1988 Election. Boulder, CO: Westview Press.

$\rightarrow$ Hall, Melinda Gann, and Paul Brace. 1989. "Order in the Courts: A Neo-Institutional Approach to Judicial Consensus." Western Political Quarterly 42(2): 391-407.

Hall, Melinda Gann, and Paul Brace. 1992. "Toward an Integrated Model of Judicial Voting Behavior." American Politics Quarterly 20(2): 147-68.

Hall, Melinda Gann, and Paul Brace. 1994a. "The Vicissitudes of Death by Decree: Forces Influencing Capital Punishment Decision Making in State Supreme Courts." Social Science Quarterly 75(1): 136-51.

Hall, Melinda Gann, and Paul Brace. 1994b. "Politics and the Administration of Justice: The Death Penalty in a Western Democracy." Presented at the 16th World Congress of the International Political Science Association, Berlin.

Hertzke, Allen D., and Robert Booth Fowler. 1995. Religion and Politics in America: Faith, Culture, and Strategic Choices. Madison, WI: Westview Press.

Himmelstein, Jerome. 1990. To the Right: The Transformation of American Conservatism. Berkeley: University of California Press. 
Johnson, Charles A., and Bradley C. Canon. 1984. Judicial Policies: Implementation and Impact. Washington, DC: Congressional Quarterly Press.

Kellstedt, Lyman A., and John C. Green. 1993. "Knowing God's Many People: Denominational Preference and Political Behavior." In Rediscovering the Religious Factor in American Politics, ed. David C. Leege and Lyman A. Kellstedt. Armonk, NY: M. E. Sharpe.

Kellstedt, Lyman A., and Corwin E. Smidt. 1993. "Doctrinal Beliefs and Political Behavior: Views of the Bible." In Rediscovering the Religious Factor in American Politics, ed. David C. Leege and Lyman A. Kellstedt. Armonk, NY: M. E. Sharpe.

Kellstedt, Lyman A., Corwin E. Smidt, and Paul M. Kellstedt. 1991. "Religious Tradition, Denomination and Commitment: White Protestants and the 1988 Election." In The Bible and the Ballot Box: Religion and Politics in the 1988 Election. Boulder, CO: Westview Press.

Leege, David C. 1993. "Religion and Politics in Theoretical Perspective." In Rediscovering the Religious Factor in American Politics, ed. David C. Leege and Lyman A. Kellstedt. Armonk, NY: M.E. Sharpe.

Leege, David C., and Lyman A. Kellstedt, eds. 1993. Rediscovering the Religious Factor in American Politics. Armonk, NY: M. E. Sharpe.

Ranney, Austin. 1976. "Parties in State Politics." In Politics in the American States, ed. Herbert Jacob and Kenneth Vines. 3d ed. Boston: Little, Brown.

Richardson, Richard J., and Kenneth N. Vines. 1970. The Politics of Federal Courts. Boston: Little, Brown.

Rozell, Mark J., and Clyde Wilcox, eds. 1995. God at the Grass Roots: The Christian Right in the 1994 Elections. Lanham, MD: Rowman \& Littlefield.

$\rightarrow$ Segal, Jeffrey A. 1984. "Predicting Supreme Court Decisions Probabilistically: The Search and Seizure Cases, 1962-1981." American Political Science Review 78 (December): 891-900.

Segal, Jeffrey A., and Harold J. Spaeth. 1993. The Supreme Court and the Attitudinal Model. New York: Cambridge University Press.

Smidt, Corwin E. 1989. "Evangelicals and the New Christian Right: Coherence versus Diversity in the Issue Stands of American Evangelicals." In Contemporary Evangelical Political Involvement: An Analysis and Assessment, ed. Corwin E. Smidt. Lanham, MD: University of America Press.

Sommerfield, Richard A. 1968. "Conceptions of the Ultimate and Social Organization of Religious Bodies.” Journal for the Scientific Study of Religion 7:178-96.

$\rightarrow$ Songer, Donald R. 1987. "The Impact of the Supreme Court on Trends in Economic Policy Making in the United States Courts of Appeals." Journal of Politics 49(3): 830-41.

Songer, Donald R., and Susan Haire. 1992. "Integrating Alternative Approaches to the Study of Judicial Voting: Obscenity Cases in the U.S. Courts of Appeals." American Journal of Political Science 36 (November): 963-82.

Songer, Donald R., Jeffrey A. Segal, and Charles M. Cameron. 1994. "The Hierarchy of Justice: Testing a Principal-Agent Model of Supreme Court-Circuit Court Interactions." American Journal of Political Science 38 (August): 673-96.

Songer, Donald R., and Reginald S. Sheehan. 1990. "Supreme Court Impact on Compliance and Outcomes: Miranda and New York Times in the United States Courts of Appeals." Western Political Quarterly 43(2): 297-319.

Speer, James A. 1984. "The New Christian Right and Its Parent Company: A Study in Political Contrasts." In New Christian Politics, ed. David G. Bromley and Anson Shupe. Macon, GA: Mercer University Press.

Stark, Rodney, and William Sims Bainbridge. 1985. The Future of Religion: Secularization, Revival, and Cult Formation. Berkeley: Uinversity of California Press.

Swierenga, Robert P. 1990. "Ethnoreligious Political Behavior in the Mid-Nineteenth Century: Voting, Values, and Cultures." In Religion and American Politics, ed. Mark Noll. New York: Oxford University Press. 
Tabrizi, Susan J. 1996. "Fundamentalist Religion and Political Attitudes in the American Mass Public." Master's thesis. University of South Carolina.

$\rightarrow$ Tate, C. Neal. 1981. "Personal Attribute Models of Voting Behavior of U.S. Supreme Court Justices: Liberalism in Civil Liberties and Economics Decisions, 1946-1978." American Political Science Review 75 (June): 355-67.

$\rightarrow$ Vines, Kenneth N. 1964. "Federal District Judges and Race Relations Cases in the South." Journal of Politics 26(2): 337-57.

Wald, Kenneth D. 1992. Religion and Politics in the United States. New York: St. Martin's Press.

Wald, Kenneth D., Lyman A. Kellstedt, and David C. Leege. 1993. "Church Involvement and Political Behavior." In Rediscovering the Religious Factor in American Politics, ed. David C. Leege and Lyman A. Kellstedt. Armonk, NY: M. E. Sharpe.

$\rightarrow$ Wenner, Lettie McSpadden, and Lee E. Dutter. 1989. "Contextual Influences on Court Outcomes." Western Political Quarterly 41(1): 113-34.

$\rightarrow$ Wilcox, Clyde. 1986. "Fundamentalists and Politics: An Analysis of the Effects of Differing Operational Definitions." Journal of Politics 48(4): 1041-51.

$\rightarrow$ Wilcox, Clyde. 1988. "The Christian Right in Twentieth Century America: Continuity and Change." Review of Politics 50 (fall): 659-81.

Wilcox, Clyde. 1996. Onward Christian Soldiers? The Religious Right in American Politics. Boulder, CO: Westview Press.

Wilcox, Clyde, Ted G. Jelen, and David C. Leege. 1993. "Religious Group Identifications: Toward a Cognitive Theory of Religious Mobilization." In Rediscovering the Religious Factor in American Politics, ed. David C. Leege and Lyman A Kellstedt. Armonk, NY: M. E. Sharpe.

Wolpert, Robin M. 1991. "Explaining and Predicting Supreme Court Decision-Making: The Gender Discrimination Cases, 1971-1987." Presented at the annual meeting of the Midwest Political Science Association, Chicago.

Donald R. Songer is Professor of Political Science, University of South Carolina, Columbia, SC 29208.

Susan J. Tabrizi is a Ph.D. candidate in political science, State University of New York at Stony Brook, Stony Brook, NY 11794-4392. 